\title{
Effects of physical activity on the quality of life among adult women
}

\author{
Klára KALMAN1, Iacob HANŢIU²
}

\begin{abstract}
Aim: the purpose of our study was to analyze the effect of a physical activity program on the quality of life of adult women. Methods: The study involved 95 adult women from Oradea, practitioners of physical exercises in a fitness center. Period of the study: February 2015 - June 2016. Anthropometric measurements were made (height, weight) and it was calculated the body mass index (BMI). The SF-36 short form questionnaire was used to assess the quality of life. The physical activity program consisted of Step - aerobics, Pilates and strength training in the gym, 3 times a week for 60-90 minutes, for 12 months.

Results: BMI revealed that of the 95 women enrolled in the initial evaluation $71 \%$ were normal weight, $16 \%$ were overweight, $8 \%$ underweight, $4 \%$ obese class I and $1 \%$ obese class II. At the final assessment $74 \%$ were normal weight, $13 \%$ were overweight, $9 \%$ underweight, $4 \%$ obese class I and no one had class II obesity. The analysis of the answers to the questionnaire revealed the following: the initial average quality of life score was 85.01 and the final score was 89.40 ; the initial average score of the physical health component was 87.54 and the final score was 92.10; the initial average score of the mental health component was 82.48 and the final score was 86.69 .

Conclusion: Applying the physical activity program for 12 months led to an improvement in the quality of life, so we can conclude that practicing physical exercise on a regular basis has the effect of increasing the quality of life.
\end{abstract}

Key words: quality of life, physical activity, SF-36 quality of life questionnaire, adult women

\section{Rezumat}

Scop: Scopul studiului nostru a fost analiza efectului unui program de activitate fizică asupra calităţii vieţii femeilor adulte. Metode: La acest studiu au participat 95 de femei adulte din Oradea, practicante a exercițiilor fizice într-o sală de fitness. Perioada studiului: februarie 2015 - iunie 2016. Au fost efectuate măsurători antropometrice (înălţimea, greutatea) și a fost calculat indicele de masă corporală (IMC). Pentru evaluarea calităţii vieţii s-a folosit chestionarul SF-36, forma scurtată, un chestionar validat, alcătuit din 36 de întrebări, care se poate aplica în studii efectuate pe o populaţie specifică sau generală. Programul de activitate fizică a constat din antrenamente combinate între Step - aerobic, Pilates şi antrenament de forță în sala de fitness, 3 ședințe pe săptămâna a 60-90 de minute, timp de 12 luni.

Rezultate: IMC la subiecții incluși în studiu arată că la evaluarea iniţială $71 \%$ au avut greutate normală, $16 \%$ au fost supraponderali, $8 \%$ subponderali, $4 \%$ au obezitate de gradul I şi 1\% obezitate de gradul II. La evaluarea finală $74 \%$ au avut greutate normală, $13 \%$ au fost supraponderali, $9 \%$ subponderali, $4 \%$ au obezitate de gradul I şi niciun subiect obezitate de gradul II. Din analiza răspunsurilor la chestionar au reieșit următoarele: scorul mediu iniţial al calitatăţii vieţii a fost de 85,01, iar cel final de 89,40; scorul mediu inițial al componentei sănătății fizice a fost de 87,54, iar cel final de 92,10; scorul mediu inițial al componentei sănătății mentale a fost de 82,48, iar cel final de 86,69.

Concluzii: Aplicarea programului de activitate fizică timp de 12 luni a dus la îmbunătăţirea calităţii vieţii, deci putem concluziona că practicarea exerciţiilor fizice în mod regulat are ca efect creșterea calităţii vieţii.

Cuvinte cheie: calitatea vieţii, activitate fizică, chestionar calitatea vieţii SF-36, femei adulte

\footnotetext{
${ }^{1}$ PhD Student, University of Babeș-Bolyai, Cluj-Napoca, Romania, Faculty of Physical Education and Sport, e-mail: nagy.klara89@yahoo.com

2 Prof., University of Babeș-Bolyai, Cluj-Napoca, Romania, Faculty of Physical Education and Sport
} 


\section{Introduction}

Quality of life is a complex concept with multiple sides, although used in everyday life, does not meet an unanimous definition of specialists. Although there is no standard definition of quality of life, it is generally accepted that it is a subjective, multidimensional assessment of the physical, psychological, and social domains of health [1].

Health-related quality of life is a particularly important issue among women. Women consistently report worse health than men. Several factors contribute to women's diminished quality of life, including a longer life span, major physiologic changes unique to women, and an increased risk of being the victim of interpersonal violence. The three physiologic changes unique to women that affect women's quality of life are menstruation, childbirth, and menopause. These changes can affect women's health both physically and mentally [2].

The WHO defines the quality of life as "individual's perceptions of their social situations, in the context of the cultural values systems they live in and according to their own needs, standards and aspirations, [3].

Farquhar defines quality of life as "the most multidisciplinary term in current use"[4]. The interest shown in the medical world for patient's quality of life issues has been demonstrated by the large number of articles on quality of life published in prestigious journals and included in the PUBMED database of the National Library of Medicine in the USA [5].

We can observe a constant and spectacular growth of articles devoted to the study of different aspects of quality of life, from 1 article between 1950-1960 to 30841 articles in the period $1991-2000$ and in 2016 to 27218 articles [6].

Quality of life depends on:

$\checkmark$ present lifestyle, past experience, hopes for the future, and the degree to which our own hopes and ambitions are achieved in everyday life [7]

$\checkmark$ things that people consider important in their lives [8]

$\checkmark$ assessing your own health by reference to an ideal model

$\checkmark \quad$ the degree to which a person is fulfilling his goals in life [9]
Quality of life has several dimensions:

1. Physical health/physical well-being: physical functioning, mobility, energy and fatigue, physical pain and discomfort, sleep and rest, optimal physical fitness, strength, suppleness and physical skills.

2. Mental health or mental/emotional well-being: including self-image, self-esteem, negative and positive feelings, feeling of security, personal convictions, spirituality, religion.

3. Social, interpersonal relationships and social integration: personal relationships, friendships, sexual activity, intimacy, family, social contacts, social support, presence of a social status and role, acceptance in different social groups, participation in community activities

4. Environment and material well-being: financial resources, property, possession of goods, physical environment (pollution, noise, traffic, climate), transport, family environment, the right food, opportunities for obtaining new information, adequate income, etc.

5. Independence: autonomy in activities of daily living, ability to work, ability to make decisions, to make personal choices, self-driving in life.

6. Ensuring fundamental human rights: freedom, right to property, right to vote, access to education, etc. [5].

In one way or another, with different names and synonyms we find common items in the questionnaires that measure the quality of life.

\section{Aim}

The purpose of our study was to analyze the effect of a physical activity program on the quality of life of adult women.

\section{Subjects and methods \\ Subjects}

The study involved 95 adult women from Oradea, practitioners of physical exercises in a fitness center. Period of the study: February 2015 - June 2016. Baseline assessment were conducted in February-March 2015. The subjects attended the gym for 12 months, and during May-June 2016 were carried out the follow-up evaluations.

The research included only those women who showed interest, accepted the measurements and 
gave permission that their data to be used in research. So it was non-random sampling, from non probabilistic sample category we used the convenience [10].

\section{Methods}

Anthropometric measurements were performed after the standards described by ISAK International Society for the Advancement of Kinanthropometry [11]: stature (in centimeters, with stadiometer); body mass/weight (in kg using a calibrated wheighing scale); it was calculated the body mass index (BMI) by formula:

BMI $=$ Weight $(\mathrm{kg}) /$ Height $^{2}\left(\mathrm{~m}^{2}\right)$

The SF-36 short form questionnaire was used to assess the quality of life, also known as MOS-SF-36 Medical Outcome Study-Short Form 36, is a validated questionnaire, consisting of 36 questions, which can be applied in studies conducted on a specific or general population. It includes 8 staging of functional health status, a summary of basic physical and mental health values and a health index. The 8 health aspects were selected from the 40 originally included in the Medical Outcome Study.

Ware and collaborators describes the most important information about the history and development of the SF-36 questionnaire, about validity studies and normative data. We also find this information in peer-reviewed articles about this questionnaire [12,13], and one of the most independent descriptions of the questionnaire development along with a critical commentary is provided by McDowell and Newell in 1996, republished in 2006 [14].

The SF-36 questionnaire contains 8 evaluation scales (Table no. I), for each one is calculated the corresponding score, represented by the average scores of the answers given to the respective items (Table no. II). The scoring of the questionnaire can be followed in tables no. I and II. In the first step the score is given for the answer to each question according to table no. II, after which the average of the items is made to form the 8 scales and to find out the separate score for each scale (Table no. I) and for the two major components: physical health and mental health. All questions are marked on a scale from 0 to 100,100 representing the highest possible level of functioning.
Table no. I Evaluation scales and corresponding items

\begin{tabular}{|l|c|l|}
\hline \multicolumn{1}{|c|}{ Scale } & $\begin{array}{c}\text { Number } \\
\text { of items }\end{array}$ & \multicolumn{1}{|c|}{$\begin{array}{c}\text { Average of } \\
\text { items }\end{array}$} \\
\hline $\begin{array}{l}\text { Physical } \\
\text { functioning }\end{array}$ & 10 & $\begin{array}{l}3,4,5,6,7,8,9, \\
10,11,12\end{array}$ \\
\hline $\begin{array}{l}\text { Role limitations } \\
\text { due to physical } \\
\text { health }\end{array}$ & 4 & $13,14,15,16$ \\
\hline $\begin{array}{l}\text { Emotional well- } \\
\text { being }\end{array}$ & 3 & $17,18,19$ \\
\hline Energy/fatigue & 4 & $23,27,29,31$ \\
\hline $\begin{array}{l}\text { Role limitations } \\
\text { due to emotional } \\
\text { problems }\end{array}$ & 5 & $\begin{array}{l}24,25,26,28, \\
30\end{array}$ \\
\hline Social functioning & 2 & 20,32 \\
\hline Pain & 2 & 21,22 \\
\hline General health & 5 & $1,33,34,35,36$ \\
\hline
\end{tabular}

Score of Physical Health $=$ (Physical functioning + Role limitations due to physical health + Pain + General health) / 4

Score of Menthal Health = $($ Energy $/$ fatigue + Social functioning + Role limitations due to emotional problems + Emotional well-being) / 4

Table no. II Scores for items by answers

\begin{tabular}{|c|c|c|}
\hline No. of question & $\begin{array}{l}\text { Original } \\
\text { answer }\end{array}$ & $\begin{array}{c}\text { Value } \\
\text { granted }\end{array}$ \\
\hline \multirow{5}{*}{$1,2,20,22,34,36$} & 1 & 100 \\
\hline & 2 & 75 \\
\hline & 3 & 50 \\
\hline & 4 & 25 \\
\hline & 5 & 0 \\
\hline \multirow{3}{*}{$3,4,5,6,7,8,9,10,11,12$} & 1 & 0 \\
\hline & 2 & 50 \\
\hline & 3 & 100 \\
\hline \multirow{2}{*}{$13,14,15,16,17,18,19$} & 1 & 0 \\
\hline & 2 & 100 \\
\hline \multirow{6}{*}{$21,23,26,27,30$} & 1 & 100 \\
\hline & 2 & 80 \\
\hline & 3 & 60 \\
\hline & 4 & 40 \\
\hline & 5 & 20 \\
\hline & 6 & 0 \\
\hline \multirow{6}{*}{$24,25,28,29,31$} & 1 & 0 \\
\hline & 2 & 20 \\
\hline & 3 & 40 \\
\hline & 4 & 60 \\
\hline & 5 & 80 \\
\hline & 6 & 100 \\
\hline \multirow{5}{*}{$32,33,35$} & 1 & 0 \\
\hline & 2 & 25 \\
\hline & 3 & 50 \\
\hline & 4 & 75 \\
\hline & 5 & 100 \\
\hline
\end{tabular}


The physical activity program consisted of Step aerobics, Pilates and strength training in the gym, 3 times a week for 60-90 minutes, for 12 months. There where used: dynamic, repetitive exercises, with large muscles groups; hard resistive exercises, high intensity interval training (HIIT), circuit training, balance exercise (Pilates), functional exercises, stretching exercises.

Muscle strenghtening was conducted mainly in the following muscle groups: upper limb muscles, back muscles, abdominal muscles, core muscles, lower limb muscles.

\section{Results}

The descriptive analysis of the demographic data of the subjects can be found in table no. III.

Table no. III. Descriptive analysis of demographic data $(\mathrm{N}=95)$

\begin{tabular}{|c|c|c|c|c|}
\hline \multirow{2}{*}{\multicolumn{2}{|c|}{ Demographic data }} & & & \\
\hline & & Mean $( \pm A S)$ & Min & Max \\
\hline \multicolumn{2}{|c|}{ Age (years) } & $28,45( \pm 8,74)$ & 18 & 52 \\
\hline \multirow{2}{*}{$\begin{array}{l}\text { Weight } \\
\text { (kg) }\end{array}$} & Baseline & $63,67( \pm 11,69)$ & 43 & 103 \\
\hline & Follow-up & $62,39( \pm 10,63)$ & 43 & 98 \\
\hline \multicolumn{2}{|c|}{ Height (cm) } & $166,88( \pm 6,36)$ & 150 & 190 \\
\hline \multicolumn{2}{|c|}{$\begin{array}{l}\text { BMI }\left(\mathrm{kg} / \mathrm{m}^{2}\right) \\
\text { Baseline }\end{array}$} & $22,86( \pm 3,76)$ & 16,61 & 36,49 \\
\hline \multicolumn{2}{|c|}{$\begin{array}{l}\text { BMI }\left(\mathrm{kg} / \mathrm{m}^{2}\right) \\
\text { Follow-up }\end{array}$} & $22,40( \pm 3,60)$ & 16,96 & 34,72 \\
\hline
\end{tabular}

After calculating BMI revealed that of the 95 women enrolled in the initial evaluation $71 \%$ were normal weight, $16 \%$ were overweight, $8 \%$ underweight, $4 \%$ obese class I and $1 \%$ obese class II. At the final assessment $74 \%$ were normal weight, $13 \%$ were overweight, $9 \%$ underweight, $4 \%$ obese class I and no one had class II obesity (figure no.1).
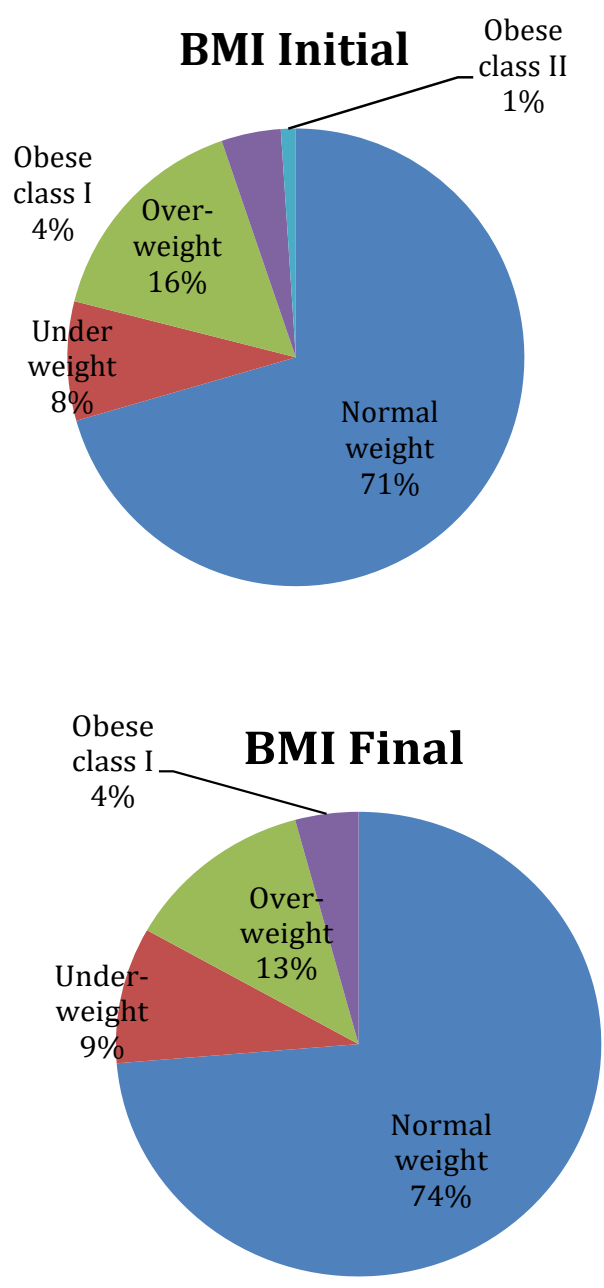

Figure nr.1. Percentage of body weight based on BMI

The analysis of the answers to the questionnaire revealed the following: the initial average quality of life score was 85.01 and the final score was 89.40; the initial average score of the physical health component was 87.54 and the final score was 92.10; the initial average score of the mental health component was 82.48 and the final score was 86.69 (table no. IV.). 
Table no.IV. Descriptive analysis of the quality of life scores registered by the study participants

\begin{tabular}{|l|l|l|c|c|}
\hline $\begin{array}{c}\text { Quality } \\
\text { of life }\end{array}$ & Initial & $85,01( \pm 8,76)$ & 49,73 & 98,25 \\
\hline $\begin{array}{c}\text { Physical } \\
\text { health }\end{array}$ & Final & $89,40( \pm 6,13)$ & 69,29 & 100 \\
\hline $\begin{array}{c}\text { Mental } \\
\text { health }\end{array}$ & Final & $87,54( \pm 9,83)$ & 50 & 100 \\
\hline
\end{tabular}

The initial and final average values can be follow separately on the two major components of the quality of life: physical health and mental health in Figure no. 2.

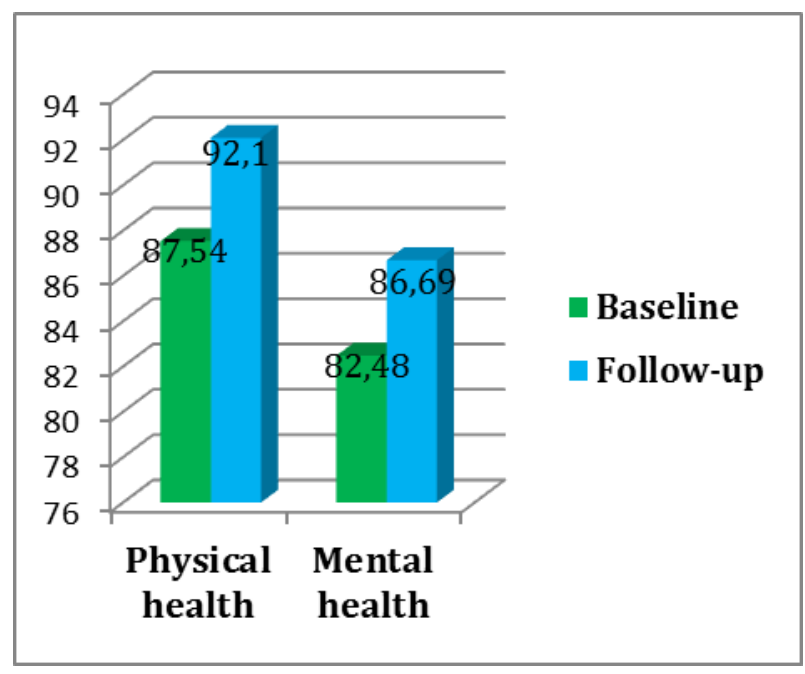

Figure no. 2 The initial and final average values of the two components of the quality of life

\section{Discussions}

The mean weight of the group at baseline was 63.67 $( \pm 11.69) \mathrm{kg}$ and at follow-up was $62.39( \pm 10.71)$ $\mathrm{kg}, 1,28 \mathrm{~kg}$ less. But we have to take into count that $8 \%$ of subjects were underweight, they wanted to gain weight, and $16 \%$ of overweight subject lost on average $2,73 \mathrm{~kg}$, respectively $4 \%$ obese subjects lost $3,25 \mathrm{~kg}$.

The average score of quality of life, after the 12month physical activity program, improved from 85.01 to 89.40 , namely by 4.39 . The physical health score increased more, 4.56 , than the mental health score, 4.21 .
An increasing transversal database supports a strong relationship between obesity and quality of life, in which the quality of life seems to decrease according to weight gain $[15,16,17,18]$.

Generally, literature has claimed that even a small weight reduction often leads to significant improvements in quality of life [19].

\section{Conclusion}

The two major components of the quality of life: physical and mental health increased both after the physical activity program, the physical health increased more, than the mental health.

Our study concluded that applying a physical activity program for 12 months leads to an improvement in the quality of life of people participating in the research, so we can say that practicing physical exercise on a regular basis has the effect of increasing the quality of life of adult women.

\section{References}

1. Guyatt G. H., Feeny D. H., Patrick D. L. (1993). Measuring health-related quality of life. Ann Intern Med.118:622-629

2. Marks J. S. (2003). Health-related quality of life among women. Chronic Disease Notes \& Reports. Vol.16 No.1, p.18, http://www.cdc.gov/hrqol/pdfs/cdnrwinter03.pdf Accessed: 10.06.2013.

3. WHO (2000). Obesity: preventing and managing the global epidemic. Report of a WHO Consultation, Geneva.

4. Farquhar M. (1995), Definitions of quality of life: a taxonomy. Journal of Advanced Nursing, 22: 502-508. doi:10.1046/j.1365-2648.1995.22030502.x

5. Lupu I. (2006). Calitatea vieţii în sănătate. Definiţii şi instrumente de evaluare,. CALITATEA VIEŢII, XVII, nr. 1-2, p. 73-91

6. www.ncbi.nlm.nih.gov/pubmed/?term=health+related+quali ty+of+life Accessed on 2017.01.26

7. Calman K. C. (1984). Quality of life in cancer patients-an hypothesis. Journal of Medical Ethics, 10(3), 124-127.

8. Carr A. J., Higginson I. J. (2001). Are quality of life measures patient centred? BMJ: British Medical Journal, 322(7298), $1357-1360$.

9. Cella D. F., Tulsky D. S. (1990) Measuring quality of life today: methodological aspects. Oncology. 4:29-38.

10. Șandor S. D. (2013). Metode și tehnici de cercetare în științele sociale. București: Tritonic.

11. ISAK (International Society for the Advancement of Kinanthropometry): International Standards for Anthropometric Assessment,2011, http://www.ceap.br/material/MAT17032011184632.pdf

12. Ware J., Jr., Sherbourne C.D. (1992). The MOS 36-Item ShortForm Health Survey (SF-36): I. Conceptual Framework and Item Selection, in Medical Care, Vol.30, No.6, pp. 473-483. Available from: https://www.researchgate.net/publication/21561645 The MOS 36-item short-form health survey SF- 
36 I Conceptual framework and item selection [accessed Feb 3, 2017].

13. Ware J., Kristin Snow, Kosinski, M., Barbara Gandek (1993). SF-36 health survey. Manual and interpretation guide. Boston, Massachusetts, The Health Institute, New England Medical Center

14. McDowell I. (2006). Measuring health: A guide to rating scales and questionnaires. (3rd ed.) New York: Oxford University Press

15. Fontaine K.R., Bartlett S.J. (2003). Health-related quality of life in obese individuals. In: Anderson RE, editor. Obesity: Etiology Assessment, Treatment, and Prevention. Champaign, IL: Human Kinetics; 2003. pp. 59-71.

16. Kolotkin R. L, Meter, K., Williams G. R. (2001). Quality of life and obesity. Obes Rev; 2:219-229. doi: 10.1046/j.1467789X.2001.00040.x. [PubMed] [Cross Ref

17. Kushner R. F., Foster G. D. (2000). Obesity and quality of life. Nutrition. 16:947-952. doi: 10.1016/S0899-9007(00)004044. [PubMed] [Cross Ref

18. Hassan M.K., Joshi, A.V., Madhavan, S.S., Amonkar, M.M. (2003). Obesity and health-related quality of life: A crosssectional analysis of the US population. Int J Obes. 27:12271232. doi: $10.1038 /$ sj.ijo.0802396.

19. Fontaine K. R., Barofsky I. (2001). Obesity and health-related quality of life. Obes Rev.; 2:173-182. doi: 10.1046/j.1467789x.2001.00032.x. 